\title{
Pemanfaatan Tanaman Obat Keluarga (TOGA) Berbasis Mangrove di Desa Sungai Rawa Kecamatan Sungai Apit Kabupaten Siak
}

Prima Wahyu Titisari ${ }^{1}$, Elfis ${ }^{1}$, Ranti Sri Widari ${ }^{1}$, Indah Riski Panggabean ${ }^{1}$, Elisabet ${ }^{1}$, Ranti Sri Widari ${ }^{1}$, Indah Riski Panggabean ${ }^{1}$, Haliza Nurdila², Putri Selaras ${ }^{2}$, Indry Chahyana ${ }^{3}$

${ }^{1}$ Program Studi Agroteknologi, Fakultas Pertanian, Universitas Islam Riau, Jl. Kaharuddin Nasution No. 113, Marpoyan, Pekanbaru, Riau, Indonesia - 28284

${ }^{2}$ Program Studi Pendidikan Biologi, Fakultas FKIP, Universitas Islam Riau, Jl. Kaharuddin Nasution No. 113, Marpoyan, Pekanbaru, Riau, Indonesia - 28284

3Program Studi Biomanajemen, Sekolah Ilmu Teknologi dan Hayati, Institut Teknologi Bandung, Jl, Ganesa No.10, Bandung, Jawa Barat, Indonesia - 40132

*Penulis koresponden: pw.titisari@edu.uir.ac.id

\begin{tabular}{l} 
Info Artikel \\
\hline Riwayat : \\
Dikirim 1 Desember 2021 \\
Direvisi 1 Januari 2022 \\
Diterima 10 Januari 2022 \\
\hline
\end{tabular}

\section{Kata Kunci :}

Toga

Mangrove

\begin{abstract}
Abstrak
Kegiatan penguatan kapasitas ibu rumah tangga dalam pemanfaatan tanaman obat keluarga (TOGA) berbasis mangrove di Desa Sungai Rawa Kecamatan Sungai Apit Kabupaten Siak. Berdasarkan observasi di lapangan diketahui bahwa beberapa ibu rumah tangga telah menanam TOGA, namun demikian jumlah TOGA yang ditanam jumlahnya terbatas. Sebagian dari mereka telah mengetahui khasiat TOGA dan secara teknis juga telah mampu mengolah TOGA, namun demikian mereka belum memahami khasiat TOGA secara ilmiah. Metoda pelaksanaan kegiatan ini berupa bimbingan teknis dengan teknik penyampaian ceramah yang digunakan untuk menyampaikan materi tentang TOGA serta demonstrasi yang digunakan untuk menunjukkan cara mempraktekkan budidaya TOGA serta pegolahannya menjadi ramuan obat keluarga. Kegiatan ini telah terlaksana dan berhasil dengan baik. Hasil pelaksanaan kegiatan dapat dicermati antara lain meningkatnya pengetahuan para ibu rumah tangga melalui pemahaman tentang aneka jenis tanaman obat berbasis mangrove. Keterampilan penanaman dan pengolahan tanaman obat menjadi minuman kesehatan yang dapat diharapkan meningkatkan mutu kesehatan keluarga. Kegiatan ini tergolong berhasil karena terjadi peningkatan pengetahuan peserta kegiatan, sebagian besar peserta menunjukkan ketrampilan yang memadai pada saat melakukan demonstrasi praktik langsung mulai dari pembuatan media tanam, penanaman, hingga pemeliharaan tanaman obat berbasis mangrove pada lahan pekarangan di Desa Sungai Rawa Kecamatan Sungai Apit.
\end{abstract}

\section{PENDAHULUAN}

Salah satu program yang dapat dilaksanakan oleh perempuan dalam upaya peningkatan kesejahteraan keluarga, khususnya di bidang pangan adalah program penanaman dan pemanfaatan Tanaman Obat Keluarga (TOGA). Program ini sekaligus menyikapi menurunnya daya beli masyarakat akibat harga obat yang semakin mahal, sehingga secara tidak langsung berdampak pada menurunnya derajat kesehatan masyarakat. TOGA adalah tanaman hasil budidaya rumahan yang berkhasiat sebagai obat. Penanaman TOGA dapat di pot atau di lahan sekitar rumah, dan jika lahan yang ditanami cukup luas maka sebagian hasil panen dapat dijual dan menambah pendapatan keluarga. Adapun pemanfaatan TOGA selain sebagai obat, juga dapat dimanfaatkan untuk: (1) penambah gizi keluarga (pepaya, timun, 
bayam), (2) bumbu atau rempah-rempah masakan (kunyit, kencur, jahe, serai, daun salam), (3) menambah keindahan (mawar, melati, bunga matahari, kembang sepatu, tapak dara, kumis kucing).

Desa Sungai Rawa merupakan salah satu desa di Kecamatan Sungai Apit Kabupaten Siak. Umumnya masyarakat di wilayah tersebut masih memiliki lahan pekarangan yang cukup luas, sehingga pemanfaatan dan pengelolaan lingkungan dapat dioptimalkan dengan penanaman TOGA. Berdasarkan observasi di lapangan diketahui bahwa beberapa ibu rumah tangga telah menanam TOGA, namun demikian jumlah TOGA yang ditanam jumlahnya terbatas. Sebagian dari mereka telah mengetahui khasiat TOGA dan secara teknis juga telah mampu mengolah TOGA, namun demikian mereka belum memahami khasiat TOGA secara ilmiah. Oleh karena itu perlu dilakukan pelatihan tentang khasiat TOGA secara ilmiah. Masyarakat yang telah memiliki pengetahuan tentang khasiat TOGA dan menguasai cara pengolahannya dapat membudidayakan tanaman obat secara individual dan memanfaatkannya sehingga akan terwujud prinsip kemandirian dalam pengobatan keluarga. Selain itu juga dapat dikembangkan menjadi usaha kecil dan menengah di bidang obat-obatan herbal, yang selanjutnya dapat disalurkan ke masyarakat.

Mengingat TOGA sangat bermanfaat untuk kesehatan, maka adanya pemanfaatan sumberdaya perdesaan berupa TOGA dengan melibatkan ibu rumah tangga di Desa Sungai Rawa Kecamatan Sungai Apit Kabupaten Siakdiharapkan mampu mendukung peningkatan kesehatan masyarakat dan sekaligus pemberdayaan perempuan dalam upaya pengentasan kemiskinan. Oleh karena itu dipandang perlu dilakukan pengabdian pada masyarakat dengan mengambil judul "Bimbingan Teknis Pemberdayaan Ibu Rumah Tangga Dalam Pemanfaatan Tanaman Obat Keluarga (TOGA) Berbasis Mangrove di Desa Sungai Rawa Kecamatan Sungai Apit Kabupaten Siak".

\section{METODE PELAKSANAAN}

Lokasi kegiatan Pengabdian (Gambar 1) pada Masayarakat dilaksanakan di Desa Sungai Rawa Kecamatan Sungai Apit Kabupaten Siak Propinsi Riau. Waktu pelaksanaan kegiatan selama 3 bulan mulai dari Maret hingga Mei 2019.

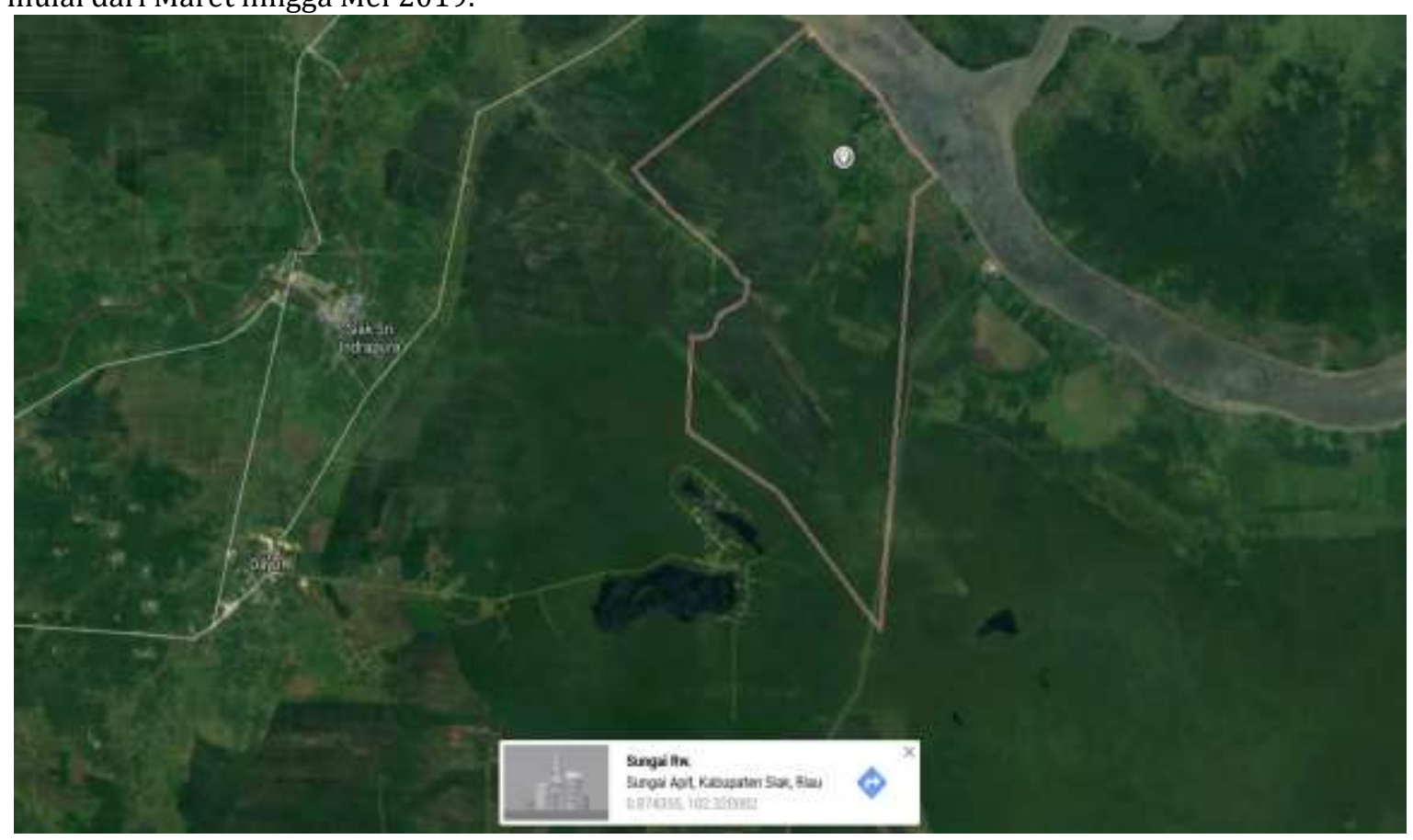

Gambar 1. Peta lokasi kegiatan pengabdian pada masyarakat di Desa Sungai Rawa Kecamatan Sungai Apit Kabupaten Siak

Sasaran dari kegiatan pengabdian kepada masyarakat ini adalah ibu-ibu rumah tangga Desa Sungai Rawa Kecamatan Sungai Apit Kabupaten Siak, ibu-ibu rumah tangga yang mengikuti kegiatan ini sekitar 25 orang. 
Keaktifan kelompok ibu-ibu ini sangat mempengaruhi hubungan sosialisasi rumah tangga dan lingkungan sosial masyarakat. Dengan potensi tersebut, hubungan ini dapat terjalin karena suatu hobi. Hobi yang ada ditemukan ketertarikan mereka terhadap tanaman obat keluarga berbasis mangrove.

1. Ceramah

Adapun metode pelaksanaan kegiatan pengabdian pada masyarakat ini adalah:

Metode ceramah yang dikombinasikan dengan menggunakan laptop dan LCD proyektor digunakan untuk menyampaikan materi tentang: (a) khasiat TOGA secara ilmiah, (b) penanaman TOGA, dan (c) pengolahan TOGA. Penggunaan metode ini dapat memberikan materi relatif banyak secara padat, cepat, dan mudah.

2. Demonstrasi

Metode demonstrasi digunakan untuk menunjukkan suatu proses kerja sehingga memberikan kemudahan bagi peserta pengabdian. Demonstrasi dilakukan oleh tim pengabdi sebagai nara sumber untuk menyampaikan atau mempraktekkan pengolahan TOGA menjadi bahan obat. berikut:

Langkah-langkah kegiatan kegiatan pengabdian pada masayarakat ini melalui tahapan sebagai

a. Persiapan, merupakan perencanaan program pengabdian yang meliputi: (a) koordinasi dengan pihak desa lokasi pengabdian, (b) penetapan waktu pelatihan, (c) penentuan sasaran dan target peserta pelatihan, dan (d) perencanaan materi pelatihan.

b. Pelaksanaan, untuk meningkatkan pengetahuan ibu rumah tangga tentang khasiat TOGA secara ilmiah dan tata cara menanam TOGA serta meningkatkan keterampilan dalam mengolah TOGA diberikan kegiatan pelatihan. Pelatihan dilakukan oleh tim pengabdi untuk penyamaan persepsi dengan peserta. Pelatihan dilakukan dengan penyediaan sarana dan prasarana kegiatan pengabdian dalam upaya peningkatan pengetahuan dan keterampilan ibu rumah tangga, meliputi penyampaian makalah tentang aneka jenis tanaman obat-obatan dan khasiatnya, tata cara penanaman tanaman obat yang baik, serta praktek pengolahan tanaman obat menjadi bahan minuman.

Tahap Operasional dan Teknis kegiatan pengabdian pada masayarakat ini melalui tahapan sebagai berikut:

\section{a. Penanaman Bibit Tanaman obat}

Kegiatan penanaman bibit tanaman obat dilaksanakan secara bersama antara Dosen dan Mahasiswa Program Studi Pendidikan Biologi FKIP Universitas Islam Riau dengan masyarakat Desa Sungai Rawa, yang dikoordinir oleh Ketua/Penggerak PKK Sungai Rawa. Kegiatan ini dimaksudkan untuk pembuatan demplot Tanaman Obat Keluarga (TOGA) berbasis tumbuhan mangrove (Gambar 2). Selain itu, kegiatan ini dilakukan untuk menumbuhkan rasa kepedulian masyarakat dalam melestarikan lingkungan. Kemudian, masyarakat nantinya mau turut serta berpartisipasi secara langsung dalam perlidungan kawasan Tanaman Obat Keluarga (TOGA) berbasis tumbuhan mangrove.

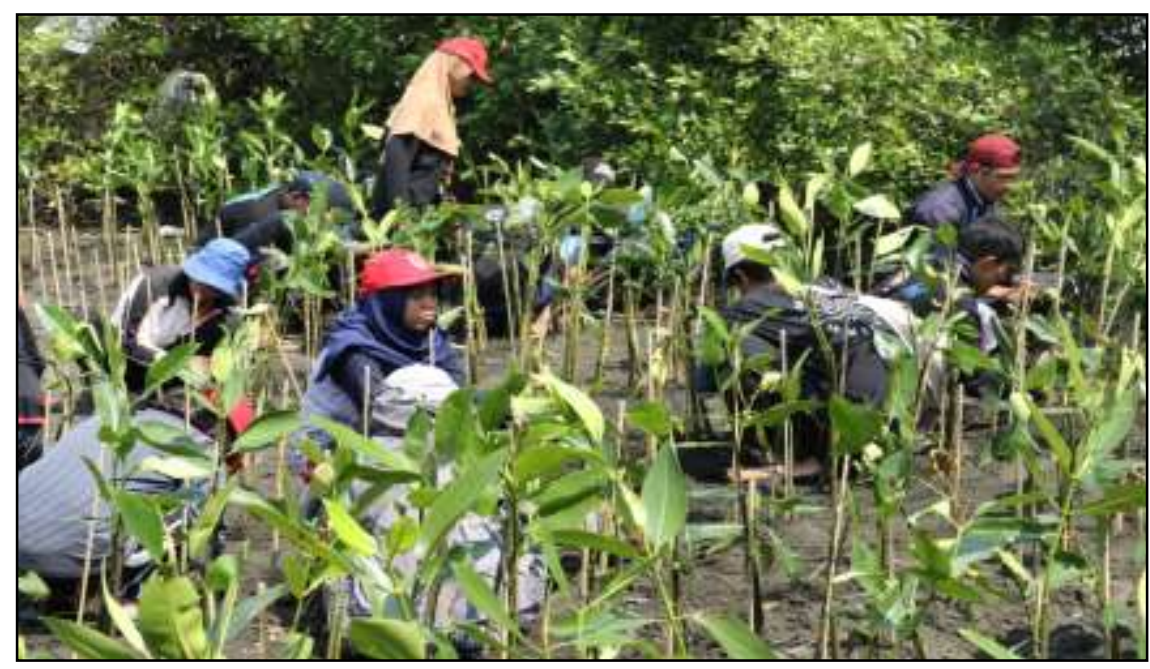

Gambar 2. Penanaman tanaman obat keluarga 


\section{b. Pembentukan Komunitas Penjaga Tanaman obat}

Pembentukan komunitas penjaga tanaman obat ini dimaksudkan untuk mengenalkan kepada masyarakat Desa Sungai Rawa mengenai pelestarian Tanaman Obat Keluarga (TOGA) berbasis mangrove, sehingga dapat menambah pengetahuan masyarakat dan khususnya kelompok Ibu-Ibu Desa Sungai Rawa.

\section{c. Penyuluhan dan implementasi TOGA}

Masyarakat yang telah mengetahui tentang tanaman obat, diharapkan menjadi tertarik untuk ikut serta dalam kegiatan Tanaman Obat Keluarga (TOGA) berbasis tumbuhan mangrove. Kegiatan ini bekerja sama dengan lembaga pengelola yang ada di Desa Sungai Rawa, Kecamatan Sungai Apit, Kabupaten Siak (Gambar 3).
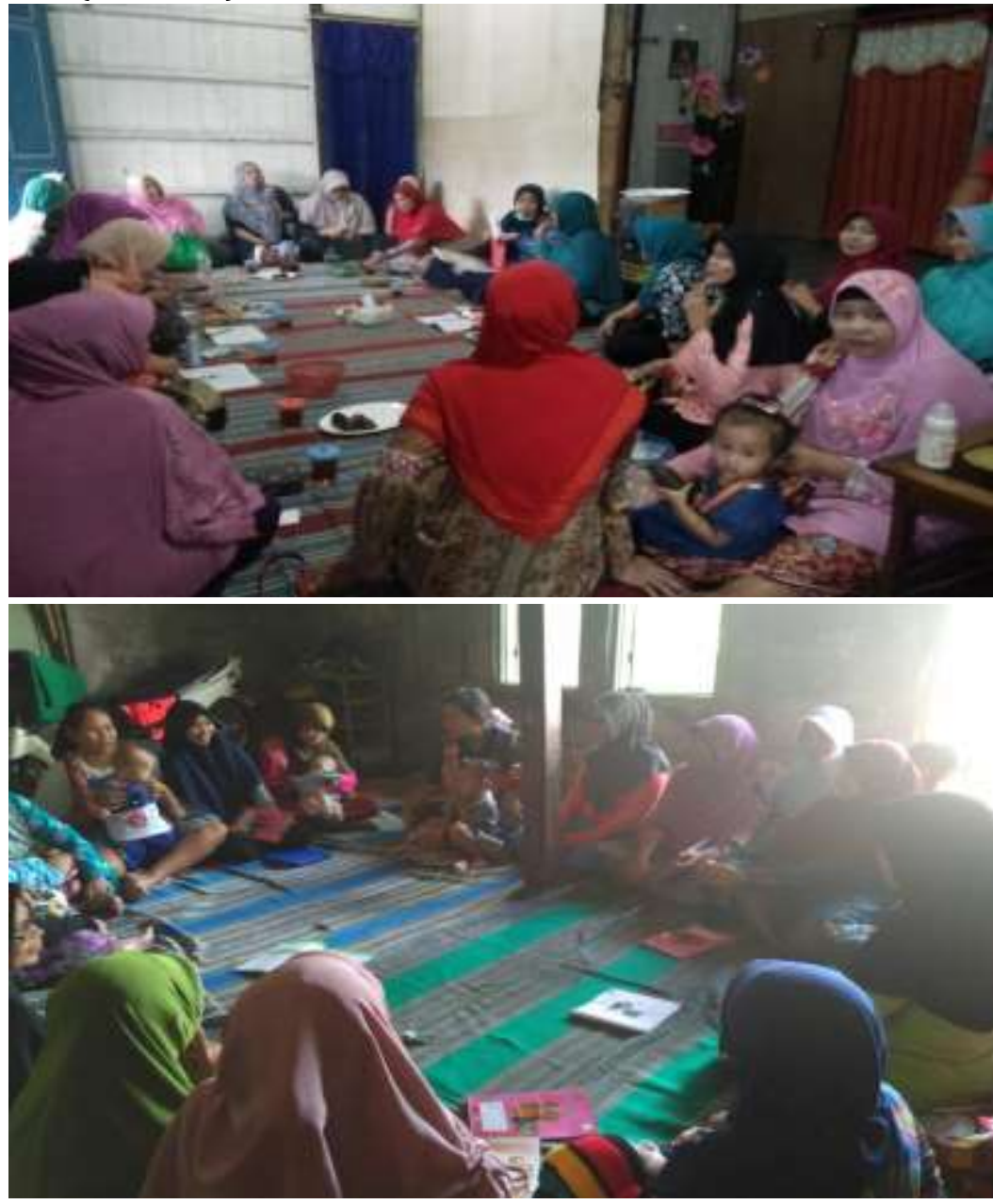

Gambar 3. Suasana sosialisasi dan penyampaian materi tanaman obat keluarga berbasis mangrove

\section{a. Tahap Monitoring dan Evaluasi}

Tahap Monitoring ini dilaksanaan karena Desa Sungai Rawa, akan dijadikan desa pengabdian masyarakat yang berkelanjutan oleh dosen. Tahap Monitoring atau pengawasan ini bertujuan untuk mengontrol semua kegiatan yang dilaksanakan di lokasi sasaran Desa Sungai Rawa. Selain itu dilaksanakan tahap evaluasi setiap akhir kegiatan dengan tujuan untuk meninjau kembali kekurangan-kekurangan yang ada dalam kegiatan pengabdian pada masyarakat sekaligus permasalahan-permasalahan yang menghambat kegiatan. Hal ini dilakukan agar pada kegiatan berikutnya kegiatan terlaksana lebih baik dari sebelumnya. 


\section{HASIL DAN PEMBAHASAN}

Hasil kegiatan pengabdian masyarakat secara garis besar dapat dilihat berdasarkan beberapa komponen berikut:

\section{Keberhasilan target jumlah peserta pelatihan}

Keberhasilan target jumlah peserta pelatihan dapat dikatakan sangat baik, dari 25 orang peserta yang diundang berdasarkan arahan pamong setempat kesemuanya dapat menghadiri kegiatan pengabdian $(100 \%)$

\section{Ketercapaian tujuan pelatihan}

Ketercapaian tujuan pelatihan dapat dikatakan baik (75\%), hal ini dikarenakan adanya peningkatan pengetahuan dari peserta tentang pengetahuan dan pemahaman dan pemberdayaan Ibu Rumah Tangga di Desa Sungai Rawa Kecamatan Sungai Apit Kabupaten Siak tentang khasiat Tanaman Obat Keluarga (TOGA) berbasis mangrove sebagai alternatif mata pencaharian masyarakat Desa Sungai Rawa.

\section{Ketercapaian target materi yang telah direncanakan}

Ketercapaian target materi yang telah direncanakan dapat dikatakan baik (80\%), hal ini dikarenakan semua materi pelatihan dapat disampaikan meskipun tidak secara detil karena waktu yang terbatas. Materi yang telah disampaikan adalah pengetahuan dan pemahaman khasiat Tanaman Obat Keluarga (TOGA) berbasis tumbuhan mangrove sebagai alternatif mata pencaharian masyarakat Desa Sungai Rawa.

\section{Kemampuan peserta dalam penguasaan materi}

Kemampuan peserta dalam penguasaan materi dapat dikatakan baik $(75 \%)$, hal ini dikarenakan penyampaian materi dengan metode ceramah dan demonstrasi dapat mendukung kemampuan peserta dalam menyerap materi yang disampaikan oleh nara sumber.

Secara keseluruhan kegiatan pelatihan restorasi mangrove serta penyuluhan tentang pengetahuan dan pemahaman khasiat Tanaman Obat Keluarga (TOGA) berbasis tumbuhan mangrove, dapat dikatakan baik dan berhasil, yang dapat diukur dari keempat komponen di atas.

Beberapa jenis tanaman mangrove yang dapat dijadikan tanaman obat keluarga (TOGA) di Desa Sungai Rawa ditunjukkan pada Tabel 1.

Tabel 1. Jenis Tanaman Mangrove yang Dapat Dijadikan TOGA

\begin{tabular}{|c|c|c|c|}
\hline No & Nama tanaman & Bagian tanaman & Khasiat obat \\
\hline 1 & Xylocarphus granatum & buah & $\begin{array}{l}\text { obat gatal/bekas cacar/penghalus } \\
\text { kulit }\end{array}$ \\
\hline 2 & Rizophora apiculata & $\begin{array}{l}\text { kulit batang akar } \\
\text { muda } \\
\text { daun }\end{array}$ & $\begin{array}{l}\text { mangir (jamur di lidah), luka baru, } \\
\text { gigi sakit, liver, kulit gatal-gatal, } \\
\text { obat muntaber }\end{array}$ \\
\hline 3 & Rizophora mucronata & daun & $\begin{array}{lcc}\text { luka digigit } & \text { kepiting } & \text { dan } \\
\text { menetralisir racun duri ikan } & \end{array}$ \\
\hline 4 & Avicer & daun & obat gatal \\
\hline 5 & Ceriol & buah, & $\begin{array}{l}\text { pengganti sirih (menguatkan gigi), } \\
\text { obat pegal linu }\end{array}$ \\
\hline 6 & Bruguiera gymnorrhiza & buah (propagul) & $\begin{array}{l}\text { mangir (jamur di lidah), pencuci } \\
\text { perut bayi, kulit gatal-gatal }\end{array}$ \\
\hline 7 & Sonneratia alba & $\begin{array}{l}\text { buah muda, kulit } \\
\text { batang, akar }\end{array}$ & $\begin{array}{l}\text { mangir nafsu makan lusiang (nyeri } \\
\text { otot, sakit pinggang, sakit tulang, } \\
\text { rematik) malaria memulihkan } \\
\text { stamina usus buntu, liver }\end{array}$ \\
\hline 8 & Nypa fruticans & $\begin{array}{l}\text { tangkai } \\
\text { muda }\end{array}$ & luka hary \\
\hline 9 & Heritiera littoralis & kulit batang & $\begin{array}{l}\text { memulihkan stamina } \\
\text { melahirkan liver }\end{array}$ \\
\hline
\end{tabular}

Berdasarkan Tabel 1, dapat kita lihat bahwa pada dasarnya masyarakat telah mengetahui beberapa jenis tanaman yang bisa dijadikan sebagai bahan obat. Gambar 4 menunjukkan beberapa contoh 
tanaman yang dapat dijadikan obat pada Desa Sungai Rawa. Daun dan kulit yang selanjutnya disebut api-api bisa untuk menyembuhkan sakit perut (diare) dan sakit asma. Untuk obat diare dan obat asma, caranya sangat mudah yaitu cukup dengan merebus beberapa lembar daun api-api lalu disaring dan air rebusannya diminum. Begitu juga dengan kulit pohon api-api, untuk bisa menyembuhkan diare cukup juga dengan meminum air rebusan kulit ini. Selain itu daun api-api juga bisa untuk menyembuhkan gatal-gatal.

Senyawa aktif yang ditemukan pada daun api-api adalah 1.2 propadiene, neftalen, dimetiltetrametil suksinat, lucidol, isofilokladen, diosepan, dan nafto yang umumnya bersifat toksis pada dosis tertentu, serta memiliki sifat antibiotik dan anti serangga. Senyawa aktif pada berbagai jaringan tanaman api-api, yaitu alkaloid, flavonoid, tanin dan saponin merupakan senyawa potensial yang dapat dimanfaatkan sebagai bahan baku industri obat-obatan. Karena itu jaringan tanaman api-api berpotensi sebagai antibiotik untuk membantu penyembuhan luka

Tanaman bakau atau Rhizophora sp, daun dan akar mudanya bisa untuk menyembuhkan luka akibat tertusuk duri ikan dan gigitan kepiting, daunnya juga bisa untuk obat luka bakar dan kulitnya bisa sebagai bahan pewarna untuk jala/pukat. Tujuan pemberian warna pada jala ikan ini adalah untuk menyamarkan warna jala sehingga tidak terlihat oleh ikan.

Xylocarpus granatum mempunyai khasiat untuk menyembuhan gatal-gatal, sebagai obat cacing juga untuk menghaluskan kulit. Caranya adalah dengan membuat buah ini menjadi bedak, buah dikupas terlebih dahulu, diiris tipis-tipis, dijemur dan setelah kering dicampur dengan beras yang telah dicuci dan dikeringkan dan dicampur dengan juga kunyit, lalu ditumbuk sampai halus dan dibuat bulatanbulatan kecil. Untuk pengobatan, bedak buah tambu ini dicampur dengan air lalu dioleskan pada bagian tubuh yang sakit gatal, untuk obat cacing bedak dioleskan pada bagian perut sedang untuk menghaluskan kulit, bedak ini bisa dioleskan pada muka dan seluruh badan. Bedak buah tambu ini lebih sering digunakan oleh kaum perempuan atau ibu-ibu terutama di siang hari, karena selain memberikan efek dingin pada badan dan muka juga agar kulit tidak cepat terbakar karena sengatan matahari.

Bruguiera gymnorrhiza menurut masyarakat bisa menyembuhkan luka dalam atau muntah darah. Caranya yaitu ambil 3 (tiga) biji buahsalasala, kupas kulitnya dan belah menjadi (2) dua bagian dicampur dengan 3 (tiga) gelas air lalu dimasak hingga air rebusannya tinggal 1 (satu) gelas, kemudian diminum 3 (tiga) kali sehari. Buah gandi-gandi (ceriops tagal) menurut masyarakat bisa digunakan sebagai pengganti sirih. Ini biasanya diperuntukkan untuk orang-orang yang telah lanjut usia, yang senang makan kapur sirih. Biasanya selain dicampur dengan sirih, juga dicampur dengan tembakau (nyirih).

Setelah dilaksanakan kegiatan pengabdian pada masyarakat di Desa Sungai Rawa dengan obyek target ibu-ibu rumah tangga, maka dapat dicermati beberapa hasil dari kegiatan yang telah dilakukan, yaitu yang pertama adalah Capaian target jumlah peserta kegiatan. Capaian target peserta yang mengikuti kegiatan pelatihan adalah 100 persen, dimana sebanyak 25 orang ibu rumah tangga menjadi peserta mengikuti kegiatan pelatihan sampai dengan selesai. Sasaran peserta dipilih berdasarkan arahan dari Ibu Kepala Desa Sungai Rawa sebagai Koordinator ibu-ibu PKK Desa Sungai Rawa. Kedua adalah capaian tujuan kegiatan.

Ketercapaian tujuan kegiatan pelatihan adalah 80 persen bisa disimpulkan baik dengan melihat hasil ukuran evaluasi pelaksanaan pelatihan menggunakan pre-test dan post test. Terdapat peningkatan pengetahuan peserta tentang khasiat aneka jenis tanaman obat dan tata cara penanamannya yang baik. Selain itu pengetahuan dan keterampilan mengolah tanaman obat menjadi bahan minuman kesehatan yang enak dan komersial.

Harapan dari program pelatihan ini bahwa ibu-ibu rumah tangga di Desa Sungai Rawa dapat melakukan praktek langsung kegiatan TOGA berbasis mangrove ini, sehingga dapat meningkatkan kesehatan dan kesejahteraan keluarga. Ketiga adalah Capaian target penyampaian materi yang telah direncanakan. Pencapaian sasaran materi yang direncanakan dapat disimpulkan baik (80\%). Materi yang disampaikan berupa aneka ragam tanaman obat berbasis mangrove yang baik, dan bagaimana cara pengolahannya menjadi minuman obat dengan waktu yang singkat namun berkat kerja keras Tim pengabdian semua berjalan lancar. 


\section{Buletin Pembangunan Berkelanjutan}

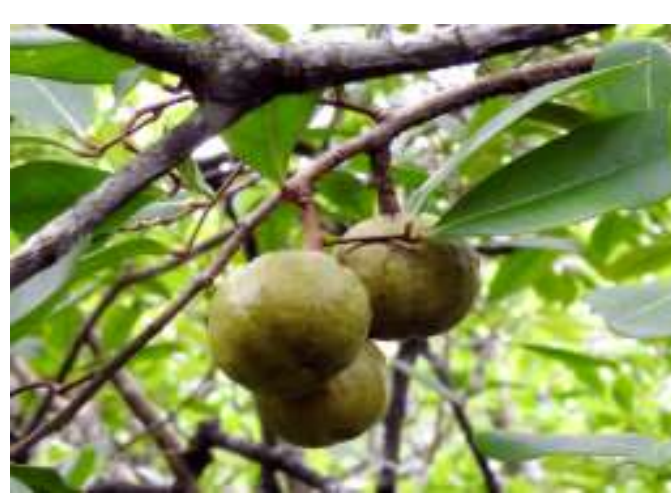

Vol. 5 No. 3, Desember 2021 hal. 45-53
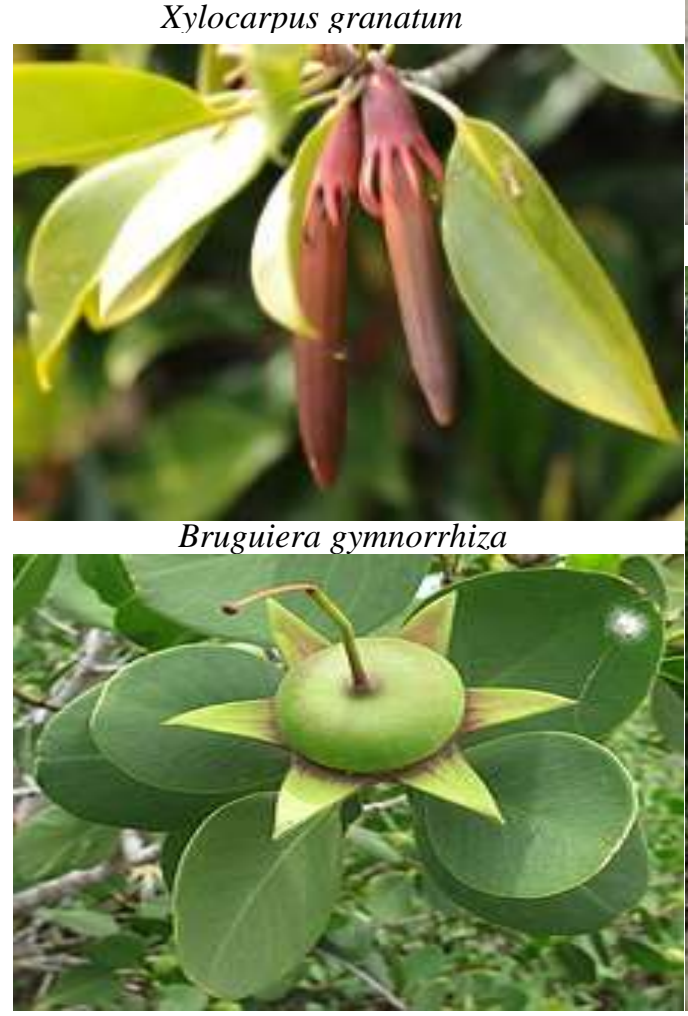

Sonneratia alba

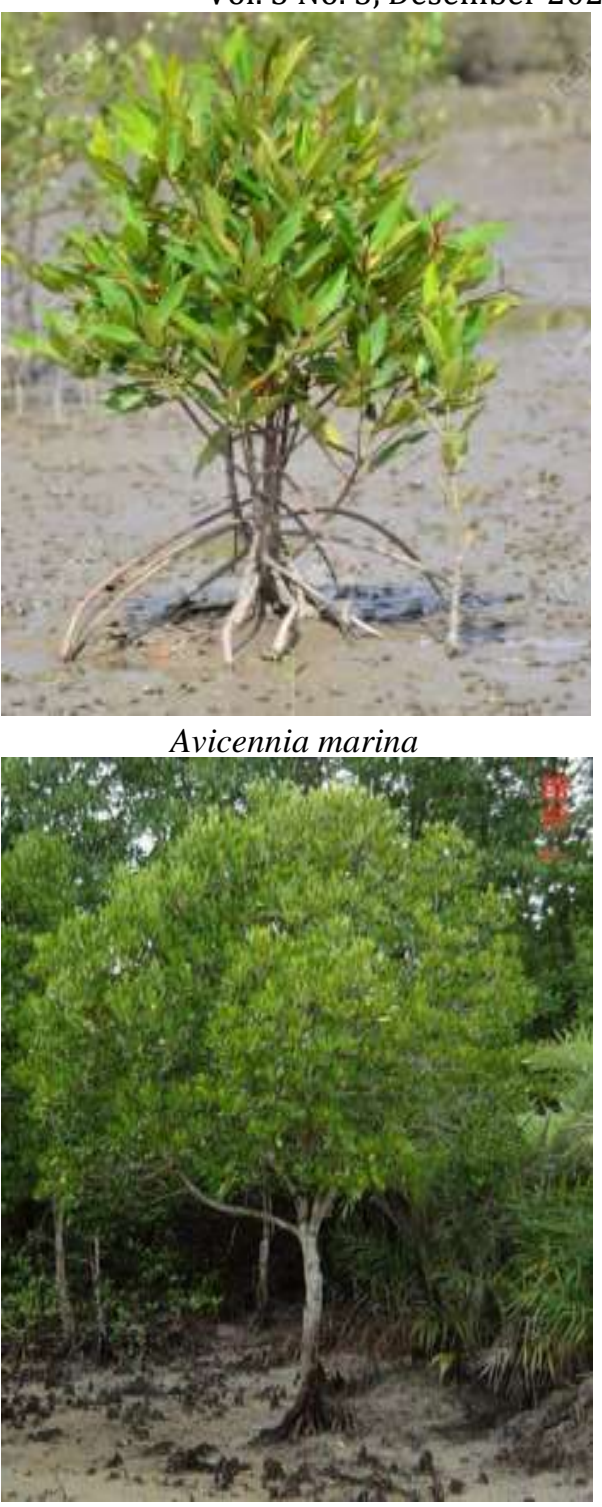

Ceriops tagal

Gambar 4. Beberapa jenis mangrove obat yang ditemukan di Desa Sungai Rawa

Dengan tingkat pemahaman peserta yang terdiri dari ibu-ibu rumah tangga dan para pemuda yaitu 75 persen. Metode yang digunakan untuk menyampaikan materi adalah dengan ceramah dan demonstrasi sangat membantu para peserta dalam menguasai materi yang diberikan oleh tim pengabdian. Secara keseluruhan kegiatan sosialisasi dan pemberian pelatihan pemanfaatan serta penanaman Tanaman Obat Keluarga (TOGA) berbasis mangrove yang dilaksanakan di Desa Sungai Rawa, Kecamatan Sungai Apit Kabupaten Siak berjalan dengan baik dan lancar. Kegiatan sosialisasi tersebut menggunakan metode ceramah dan demonstrasi dapat memberikan dan menambah pengetahuan tentang tata cara penanaman tanaman obat yang baik. Masyarakat yang telah memiliki pengetahuan tentang khasiat TOGA berbasis mangrove dan menguasai cara pengolahannya dapat membudidayakan tanaman obat secara individual dan memanfaatkannya sehingga akan terwujud prinsp kemandirian dalam pengobatan keluarga. Selain itu juga dapat dikembangkan menjadi usaha kecil dan menengah di bidang obat-obatan herbal, yang selanjutnya disalurkan kepada masyarakat. Berdasarkan evaluasi atas program pengabdian pada masyarakat di Desa Sungai Rawa di atas maka secara umum kegiatan telah dilaksanakan dengan baik dan berhasil. Hal ini dapat dilihat dari analisis pelaksanaan kegiatan sosialiasi dan pemberian pelatihan terkait Tanaman Obat Keluarga (TOGA) berbasis mangrove. 


\section{KESIMPULAN}

Kegiatan penguatan kapasitas ibu rumah tangga dalam pemanfaatan tanaman obat keluarga di Desa Sungai Rawa Kecamatan Sungai Apit Kabupaten Siak telah dilaksanakan dengan baik dan lancar. Hasil analisis terhadap kegiatan dapat dicermati antara lain meningkatnya pengetahuan para ibu rumah tangga. Peran ibu rumah tangga semakin kuat dalam mendukung kesehatan keluarga dan meningkatkan kesejahteraan keluarga melalui pemahaman tentang aneka jenis tanaman obat keluarga. Keterampilan penanaman dan pengolahan tanaman tersebut menjadi minuman kesehatan yang dapat meningkatkan penghasilan keluarga.

PKM ini tergolong berhasil karena terjadi peningkatan pengetahuan sekitar 80 persen dibandingkan saat belum dilakukannya alih teknologi dan demonstrasi praktik langsung budidaya TOGA berbasis mangrove. Seluruh peserta menunjukkan ketrampilan yang memadai pada saat melakukan demonstrasi praktik langsung mulai dari pembuatan media tanam, penanaman, hingga pemeliharaan tanaman obat di lahan pekarangan. Pengembangan tanaman obat di polibag dapat meningkatkan mutu pekarangan sekitar tempat tinggal peserta kegiatan.

Kegiatan pengabdian pada masyarakat ini diharapkan dapat mencapai tujuan akhir melalui pemberi materi pelatihan menggunakan metode ceramah dan juga demonstrasi. Selanjutnya, hasil kegiatan ini hendaknya dapat ditindaklanjuti oleh pemerintah setempat dengan dukungan seluruh masyarakat didesa sehingga, terwujudnya peningkatan kesejahteraan masyarakat desa. Tahapan berikutnya diharapkan adanya perluasan dan kedalaman materi pelatihan berupa manajemen pemasaran TOGA berbasis mangrove agar dapat meningkatkan kesejahteraan keluarga.

\section{UCAPAN TERIMA KASIH}

Penghargaan dan ucapan terima kasih disampaikan kepada pihak Direktorat Penelitian dan Pengabdian Masyarakat (DPPM) Universitas Islam Riau Pekanbaru melalui Skema Pendanaan Pengabdian Masyarakat Internal Tahun Anggaran 2019 sehingga kegiatan pengabdian masyarakat ini bisa terlaksana dengan baik dan lancar. Terima kasih juga disampaikan kepada Pimpinan dan masyakarat Desa Sungai Rawa Kecamatan Sungai Apit Kabupaten Siak selaku mitra kegiatan pengabdian, dan juga kepada Kepala Sungai Rawa atas izin pelaksanaan pengbdian masyarakat ini.

\section{DAFTAR PUSTAKA}

Abubakar, S. (2011) Pemanfaatan Mangrove Bagi Peruntukan Sediaan Farmasitika (Suatu Studi Etnofarmakologis) Di Desa Lola Kecamatan Oba Kota Tidore Kepulauan. Jurnal Vegetasi Biologi, 1 (2) : 73-83

Arini DID (2018) Pengetahuan lokal Masyarakat Sulawesi Utara dalam pemanfaatan pohon hutan sebagai bahan obat tradisional. Jurnal Masyarakat dan Budaya. 19: 161-174.

Bardan SN (2007) Tanaman Berkhasiat Obat. PT Sunda Kelapa Pustaka, Jakarta.

Efremila E, Wardenaar L, Sisillia L (2015) Studi Etnobotani Tumbuhan Obat Oleh Etnis Suku Dayak di Desa Kayu Tanam Kecamatan Mandor Kabupaten Landak. Jurnal Hutan Lestari. 3:234-246.

Kementrian Pertanian (2019) Tanaman Obat. Badan Penelitian Tanaman Rempah Dan Obat.

Larassati A, Marmaini, Trimin K (2019) Inventarisasi Tumbuhan Berkhasiat Obat Di Sekitar Pekarangan Di Kelurahan Sentosa. Jurnal Indobiosains. 1: 76-89.

Lingkubi JR, Sumakud MY, Nurmawan W, Pangemanan EF (2015) Pemanfaatan Tumbuhan Obat di Kecamatan Bunaken, Kota Manado, Provinsi Sulawesi Utara. In Cocos, 6: 1-9.

Mindari S, Nurbaeti B. 2015. Buku Saku Tanaman Obat Keluarga (TOGA): Balai Penelitian Dan Pengembangan Pertanian Kementrian Pertanian, Jakarta

Pelokang CY, Koneri R, Katili D (2018) Pemanfaatan Tumbuhan Obat Tradisional oleh Etnis Sangihe di Kepulauan Sangihe Bagian Selatan, Sulawesi Utara. Jurnal Bioslogos. 8: 45- 51.

Qamariah N, Mulyani E, Dewi N (2018) Inventarisasi Tumbuhan Obat Di Desa Pelangsian Kecamatan Mentawa Baru Ketapang Kabupaten Kotawaringin Timur. Borneo Journal of Pharmacy. 1: 1-10.

Wibowo, C., Kusmana, C., Suryani, A., Hartati, Y. dan Oktadiyani, P. (2009) Pemanfaatan Pohon Mangrove Api-api (Avicennia spp) sebagai bahan pangan dan obat. Proseding seminar hasil-hasil penelitian IPB: 158166.

Yowa MK, Boro TL, Danong MT (2019) Inventarisasi Jenis-Jenis Tumbuhan Berkhasiat Obat Tradisional Di Desa UmbuLangang Kecamatan Umbu Ratu Nggay Barat Kabupaten Sumba Tengah. Jurnal Biotropikal Sains. 16: 1 - 13. 
Buletin Pembangunan Berkelanjutan

Vol. 5 No. 3, Desember 2021 hal. 45-53

Zuhud EA, Hidayat M (2009) Potensi Hutan Tropika Indonesia sebagai penyangga bahan obat alam untuk kesehatan bangsa. Jakarta. 